\title{
THE IMPACT OF THE COVID-19 PANDEMIC ON THE USE OF MOBILE APPLICATIONS BY THE LOCAL POPULATION IN THE SMART TOURISM DESTINATION
}

\author{
Zrinka Zadel \\ Nikolina Šerić Honović \\ Damir Magaš
}

https://doi.org//10.20867/tosee.06.53

\begin{abstract}
Purpose - During the COVID-19 pandemic, the ways of using technology have expanded, i.e. more and more residents in their area have been using the advantages of technology development for satisfying their everyday needs. The purpose of this paper is to determine the impact of the COVID-19 pandemic on the use of mobile applications by the local population in Rijeka as a smart tourism destination.

Methodology - The research will be conducted in the form of a structural questionnaire among the local population of the city of Rijeka. The extent to which the local population has been using smart technology in Rijeka before and during the pandemic will be explored. The descriptive statistics and t-test will be used to analyse the research results.

Findings - The paper will determine the importance of smart technology for both locals and tourists. The analysis of the research results will define which smart technologies in the pandemic conditions make it easier for the local population to fulfil their everyday obligations, and therefore also for tourists who mainly arrive to satisfy their basic life needs.

Contribution - The obtained research results will be of use to the destination management when designing the tourism product of the destination because the research will provide the information on which smart technologies are necessary to be developed in order to meet the basic needs of tourists in a destination which is safe and easy to "consume". Today, the decision to travel is primarily influenced by the protection of tourists' health in a destination.
\end{abstract}

Keywords: smart destination; mobile applications; the impact of the COVID-19 pandemic; local population.

\section{INTRODUCTION}

Throughout history, tourism was influenced by various negative global issues. Between 2000 and 2015, major disruptive events included the September 11 terrorist attacks (2001), the severe acute respiratory syndrome (SARS) outbreak (2003), the global economic crisis unfolding in 2008-2009, and the 2015 Middle East respiratory syndrome (MERS) outbreak (Gössling et al. 2020). Today, tourism has to face the COVID-19 pandemic which currently has the strongest global negative impact. This is the first widespread pandemic which closed all tourism destinations in March 2020 since travelling enables the pandemic to spread quickly and easily. The main reasons for this lie in the processes of globalisation and global change of which travel and tourism are integral components (Burkle 2006; Hall 2020; Allen et al. 2017). The tourism 
ToSEE - Tourism in Southern and Eastern Europe, Vol. 6, pp. 803-815, 2021.

Z. Zadel, N. Šerić Honović, D. Magaš: THE IMPACT OF THE COVID-19 PANDEMIC ON THE USE ...

destinations had to deal with a serious challenge, so the scientists and experts tried to come up with a response to the COVID-19 pandemic. In these new conditions, every tourism destination had to come up with a solution for this serious new challenge: how to attract tourists and make them feel protected during the stay. In May 2020, UNWTO released Global Guidelines to Restart Tourism (UNWTO) which focused on seven priorities for tourism recovery. The emphasis was put on the increased use of technology in order to reduce the physical contact between all tourism stakeholders. The pandemic sparked the trend of increased use of technology in a destination. According to the last research conducted by the Institute for tourism (2019), more than half of the tourists in the Republic of Croatia use the internet as a source of information.

The use of technology is one of the ways for reducing physical contact. The increased use of technology can be expected in the case of destinations which already have a developed infrastructure such as smart cities and smart destinations. The functions of a smart city are closely connected with satisfying the needs of the local population (Lii Inn 2020), while a destination can be called smart when it makes intensive use of technology in order to enhance the visitors' tourist experience by personalizing their destination offer (Lamsfus, De Canto and Alzua-Sorzabal 2015). The goals of a smart tourism destination are to increase competitiveness and improve the quality of life of all stakeholders, including residents and tourists (Caragliu et al. 2011).

Therefore, in this paper, the formulated hypothesis that the pandemic influenced the increased use of mobile technology by the local population in terms of indirect tourism capacities, will be tested in Rijeka which is an example of a smart city and a smart tourism destination.

In the November of 2020 at the conference "Sustainable Cities" held in Zagreb, the research "Analysis of digital readiness of Croatian cities 2020" was presented within which the City of Rijeka was named the best city in Croatia in the Smart city category. Some of the criteria that were evaluated in determining the Smart city standard concern: Smart administration: the use of technology in the work of city administrations, eservices, e-citizens; Greenfield programs: technology incubators, city incentives for companies engaged in ICT technology; Utilities: e-bills, energy savings through smart public lighting; Transport: smart parking, infrastructure (traffic lights, roundabouts), public transport harmonized with the use of technology; Security: use of technologies in the security of citizens, detection/prevention of crime, public alarms; Community life: smart parks, public WIFI, etc. According to the document of the Institute of Economics in Zagreb (2018) Rijeka is also one of the eleven smart cities in Croatia - Pazin, Dubrovnik, Varaždin, Pula, Rijeka, Zadar, Čakovec, Split, Koprivnica, Samobor and Karlovac.

There are no specific factors of smart tourism destination, but they should be built on top of the constructs of smart cities. As with Smart Cities, Smart Tourism Destinations can increase their competitiveness (Ritchie and Crouch 2005) and with the implementation of technologies enhance its tourism experiences (Neuhofer et al. 2012). Because of the list of smart cities in Croatia, which have the most important preposition to be smart dstination, as well, for this research was choosen city of Rijeka. 
ToSEE - Tourism in Southern and Eastern Europe, Vol. 6, pp. 803-815, 2021.

Z. Zadel, N. Šerić Honović, D. Magaš: THE IMPACT OF THE COVID-19 PANDEMIC ON THE USE ...

The research was conducted among the local population in the form of a structured questionnaire, while the SPSS software package, i.e. the descriptive statistics methods, were used for data analysis and the t-test was conducted in order to determine if there is a significant difference between men and women in using mobile applications.

\section{LITERATURE REVIEW}

The tourism market trends have an influence on the development of a tourism destination. Tourists' preferences and demands form a tourism destination (Beritelli et al. 2015; Dredge 1999; Leiper 1990). A tourist place is the central point of a smart tourism destination which developed as a result of tourists' needs. For a relatively long time, the term tourist place was adequate to respond to tourist preferences. Kaspar (Magaš 2003) describes a tourist place as the „point of crystallization“ of tourism demand emphasizing that the tourism demand is directed at a particular place which has to be determined from the aspect of the tourist.

The term tourism destination was created because the area where tourism activity took place needed to be defined in more detail. The term tourism destination defines the area which the destination covers as well as the main criteria which a particular place has to meet in order to be considered a tourism destination. Magaš (2018) claims that a tourism destination represents an optimal combination of fixed and variable factors along with the possibility to carry out tourism activities in accordance with the market preferences, regardless of the administrative boundaries. In 2019, the Republic of Croatia defined the term tourism destination in the Law on Tourist Boards and the Promotion of Croatian Tourism (Law of tourist boards and the promotion of croatian tourism, 2019) as a market and tourism valorised area which represents the goal of tourist travels covering the area of one or more local or regional self-government units. Leiper (1990) has defined tourism destinations from a demand-side perspective as a geographical area to which tourists travel to visit attractions. UNWTO defines a tourism destination as the main destination of a tourism trip, i.e. as the place visited that is central to the decision to take the trip (UNWTO). All of the above leads to the conclusion that a tourism destination represents an area with adequate tourism offer.

The increasing influence of globalization and the changes in tourist preferences led to further modifications in the development of a tourism destination which eventually transformed into a smart tourism destination. In order to be able to develop into a smart tourism destination, a city or a place has to meet the criteria of a smart city. Essentially, the smart tourism destination represents an adaptation to the tourism of the smart cities concept (Gretzel et al. 2015). Smart cities are understood as being urban spaces where information and communication technologies (ICTs) play a fundamental role in the design of innovative urban spaces in order to facilitate their sustainability and improve the lives of their inhabitants (Buhalis and Amaranggana 2015; Ivars et al. 2016). The concept of smart cities and the one of smart tourism destinations are not the same. The concept of a smart tourism destination ultimately arises from the notion of smart cities (Zhu et al. 2014), but focusing more on the tourism development (Sigalat-Signes, CalvoPalomares, Roig-Merino and Garcia-Adan 2019). Every smart tourism destination is also a smart city, but every smart city is not necessarily a smart tourism destination. 
ToSEE - Tourism in Southern and Eastern Europe, Vol. 6, pp. 803-815, 2021.

Z. Zadel, N. Šerić Honović, D. Magaš: THE IMPACT OF THE COVID-19 PANDEMIC ON THE USE ...

When defining a smart tourism destination, the emphasis is placed on smart technologies. Smart tourism destinations are innovative tourism destinations built on an infrastructure of modern technology promoting the sustainable and accessible development of tourist areas which are designed to improve the tourist experience and residents' quality of life (Gretzel et al. 2015). The smart tourism destinations are places which utilise available technological tools and techniques to enable demand and supply to create value, pleasure and experiences for tourists and wealth, profit and benefits for the organisations and the destination (Guo, Liu, and Chai 2014). According to some authors (Santos-Júnior et al. 2017) a smart tourism destination is «an innovative tourist destination, built on an infrastructure of state-of-the-art technology guaranteeing the sustainable development of the tourist area, accessible to everyone, which facilitates the visitors' interaction with and integration into their surroundings, increases the quality of the experience at the destination, while also improving the quality of life of its residents» (Santos-Júnior et al. 2017). A tourism destination becomes a smart tourism destination if there is a technological infrastructure which facilitates the consumption of the tourism product. The concept of a smart destination is used for destinations where technology influences the tourist experience, increases the competitiveness of the destination (Neuhofer et al. 2012) and promotes development projects in tourism (Boes et al. 2015; Presenza et al. 2014).

The use of technology exhibits exponential growth which has an impact on the tourism industry. It has been reported that 40 per cent of smartphone users look for travel information on their mobile devices, and 11,000 iPhone travel applications are available as of April 2010 (Bressler 2010).

When making use of smart technology, destinations gain multiple advantages in terms of both demand and supply. From the aspect of the supply, it provides a new form of marketing and communication channels, while from the aspect of the demand, the tourists are better-informed and can then combine different tourism products which will best fulfil their expectations. A study tested the usability of STTs and illustrated that tourists' overall travel quality increases when tourists perceive accessibility, ease of navigation, and visual attractiveness in STTs.

The tourists at a destination use smart tourism technologies for the consumption of primary tourism products such as airline tickets, car rental and accommodation, but also for the consumption of secondary tourism products related to indirect tourism capacities which include buying museum tickets or shopping and buying other basic products by using mobile applications (Xiang et al. 2015). The indirect tourism capacities are mainly intended for the local population, but are also used by tourists when they arrive at a destination. Due to the smart technology, a smart destination becomes attractive and more accessible to tourists, but also to the local population since it contributes to the development of interactive services which connect various local organisations making it possible for the consumers to quickly gain access to the needed information and services (Liberato at al. 2018).

The smart technology in a smart tourism destination involves any form of IT that tourists interact with for information search, transaction, communication and content generation and includes smartphone apps, websites of online travel agencies and destination's smart 
ToSEE - Tourism in Southern and Eastern Europe, Vol. 6, pp. 803-815, 2021.

Z. Zadel, N. Šerić Honović, D. Magaš: THE IMPACT OF THE COVID-19 PANDEMIC ON THE USE ...

infrastructure, where smartphone applications are especially important (Wang et al. 2012).

The COVID-19 pandemic dictates new tourist behaviours which determine a new approach to tourists at a destination. The protection of tourists' health has become imperative. In order to ensure a safe environment for the tourists' health at a destination, it is necessary to respect the epidemiological measures which imply social distancing. The tourists' recent desire to make contact with as much locals as possible has now been replaced with the necessity to minimise social contact in order to protect their health. Therefore, it is necessary to maximally reduce the tourists' social contact during the consumption of the tourism products at a destination. Even before the pandemic, technology has already emerged as a key driver of change in the tourism industry (Neuhofer et al. 2014).

The purpose is to discover new habits of the local population related to the use of technology, that is, the use of mobile applications for fulfilling everyday obligations compared to the time before the coronavirus pandemic.

\section{EMPIRICAL RESEARCH OF USING MOBILE APPLICATIONS DURING THE COVID-19 PANDEMIC}

There are scientific papers (Boes, Buhalis and Inversini 2015; Gretzel et al. 2015; Buhalis and Amaranggana 2015) about the importance of technologies for the development of tourism destinations, ie. about their becoming smart tourism destinations Authors Liberato, Alen and Liberato (2018) in their paper suggest to deepen the knowledge of the effects of technologies on the tourism experience in other smart destinations. They have done research in Porto (Portugal) and have recommend to do research in more tourist destinations. The have done it among tourist, and this research is done among local population because of COVID-19 but the intention is to do it again among tourists and after COVID-19 is finished, among local population again.

The empirical research, as a part of this paper, was conducted in the form of a questionnaire among the local population of the city of Rijeka. The questionnaire consisted of four parts. In the first part of the questionnaire the participants were asked to provide their socio-demographic data. The second part consisted of questions related to their preferences about using different mobile applications during the COVID-19 pandemic as well as questions about their satisfaction with the mentioned applications. The third part included five questions referring to the specific types of mobile applications and the participants' preferences for using them during, but as well as before the pandemic. The last part of the questionnaire consisted of two questions related to travelling during the pandemic. Out of the 87 collected questionnaires, 70 of them were filled out correctly and used for the data analysis. The research was conducted during one week in March while the social networks were used to select the participants. The hypothesis formulated for this research was as follows: In terms of using indirect tourism capacities, the COVID-19 pandemic influenced the increased use of mobile applications by the local population. 
ToSEE - Tourism in Southern and Eastern Europe, Vol. 6, pp. 803-815, 2021.

Z. Zadel, N. Šerić Honović, D. Magaš: THE IMPACT OF THE COVID-19 PANDEMIC ON THE USE ...

There were 46 female and 24 male participants in the research. Regarding the age groups, the greatest number of participants $(87,1 \%)$ belonged to the age group from 19 to 29 years old, while just one participant was between 40 and 49 years old, three of them belonged to the group from 16 to 18 years old and six participants were between the age of 30 and 39 . The greatest number of participants $(61,4 \%)$ finished high school while only three $(4,3 \%)$ earned a master's or doctoral degree. The reason behind this large number of young participants can be found in the way the questionnaire was distributed since it is assumed that these are the generations which use social networks the most.

The last three questions in this group were: „Do you own a smartphone?“, “Do you use mobile applications for communication?" and "Do you have experience in using mobile applications for buying products/services?”. All of the participants answered ,yes" to the first two questions, while only six participants answered „no“ to the third question.

Further in the questionnaire, the participants were asked to specify their level of agreement with ten statements. They had the option of choosing one point on the Likert scale, ranging from 1 to 5 . The point 1 signified strong disagreement with the statement, point 2 signified disagreement, point 3 neither disagreement nor agreement, point 4 signified agreement and point 5 strong agreement with the statement. The first out of the ten statements was the following: „During the pandemic, I used mobile applications for buying products/services more often than usual." The greatest number of participants $(30 \%)$ selected the point 3 for this statement and $27,1 \%$ of them the point 4 . The next statement was as follows: „Because of the mobile applications I was able to fulfil more obligations during the pandemic than I would have been able to do in person" for which 25 participants chose the point 3 and 17 participants the point 5 . The third statement: "The mobile applications for buying products/services enabled me to behave responsibly during the pandemic (staying at home, not going to the stores)" was rated with the point $4(39 \%)$ and point $5(28,6 \%)$ by the greatest number of participants as expected. As for the following statement: "During the pandemic, using mobile applications for buying products/services made me feel safer", most of the participants $(27 \%)$ answered they agree with this statement, 17 participants responded they neither disagree nor agree, while 16 participants strongly agreed with this statement. The fifth statement was the following: "The use of mobile applications for buying products/services made my days in isolation more interesting". The greatest number of participants $(27,1 \%)$ selected the point 4 for this statement, while $25,7 \%$ of them selected the point 3 . As for the next statement „I feel comfortable when using mobile applications for buying products/services“, 22 participants $(31,4 \%)$ decided to choose the point 5 and $27,1 \%$ the point 4. The statement "I feel safe when using mobile applications for buying products/services" was marked with the point 4 by $34,3 \%$ of the participants. The last three questions in this group referred to the satisfaction and recommendation of mobile applications for buying products/services. With this in mind, the eighth statement was: "In general, I am satisfied with the experience of using mobile applications for buying products/services" where $41,4 \%$ of the participants selected the point 4 . The greatest number of participants $(32,9 \%)$ selected the same point for the statement "I will continue to use mobile applications for buying products/services after the pandemic". As for the last statement "I will recommend mobile applications for buying products/services to my family and friends", most of the participants $(31,4 \%)$ chose the point 3 . It can be concluded that the participants marked each of the statements with higher points, which 
ToSEE - Tourism in Southern and Eastern Europe, Vol. 6, pp. 803-815, 2021.

Z. Zadel, N. Šerić Honović, D. Magaš: THE IMPACT OF THE COVID-19 PANDEMIC ON THE USE ...

means mobile applications played a significant role during the pandemic and the participants were satisfied with them.

The following table is a quantitative representation of the previously described results by the mean and standard deviation for each of the ten statements.

\section{Table 1: Results of descriptive analysis $(\mathbf{N}=\mathbf{7 0})$}

\begin{tabular}{lcc}
\hline Dimensions & Mean & SD \\
\hline $\begin{array}{l}\text { Usefulness of mobile apps } \\
\begin{array}{l}\text { During the pandemic, I used mobile applications for buying } \\
\text { products/services more often than usual. }\end{array}\end{array}$ & $\mathbf{3 , 4 8}$ & $\mathbf{0 , 0 3}$ \\
$\begin{array}{l}\text { Because of the mobile applications I was able to fulfil more obligations } \\
\text { during the pandemic than I would have been able to do in person. }\end{array}$ & 3,34 & 1,21 \\
$\begin{array}{l}\text { The mobile applications for buying products/services enabled me to } \\
\text { behave responsibly during the pandemic (staying at home, not going to } \\
\text { the stores). }\end{array}$ & 3,57 & 1,26 \\
\hline $\begin{array}{l}\text { Attitude towards mobile apps } \\
\begin{array}{l}\text { During the pandemic, using mobile applications for buying } \\
\text { products/services made me feel safer. }\end{array}\end{array}$ & $\mathbf{3 , 4 3}$ & $\mathbf{0 , 0 5}$ \\
$\begin{array}{l}\text { The use of mobile applications for buying products/services made my } \\
\text { days in isolation more interesting. }\end{array}$ & 3,33 & 1,34 \\
$\begin{array}{l}\text { I feel comfortable when using mobile applications for buying } \\
\text { products/services. }\end{array}$ & 3,36 & 1,31 \\
$\begin{array}{l}\text { I feel safe when using mobile applications for buying products/services. } \\
\text { Intent to use mobile apps }\end{array}$ & 3,63 & 1,26 \\
$\begin{array}{l}\text { In general, I am satisfied with the experience of using mobile applications } \\
\text { for buying products/services. }\end{array}$ & 3,41 & 1,22 \\
$\begin{array}{l}\text { I will continue to use mobile applications for buying products/services } \\
\text { after the pandemic. }\end{array}$ & 3,79 & $\mathbf{3 , 0 9}$ \\
$\begin{array}{l}\text { I will recommend mobile applications for buying products/services to my } \\
\text { family and friends. }\end{array}$ & 3,76 & 1,12 \\
\hline
\end{tabular}

Source: Authors

Unlike the previously discussed individual statements, the aforementioned and described statements were divided into three groups in the table so it would be possible to calculate the mean by group. The mean of each group clearly revealed a non-attachment to mobile applications even though the only way to get certain products/services during the pandemic was to buy them online. It is optimistic that the highest mean by group was related to the satisfaction and the willingness to recommend mobile applications, even though it is still necessary to gain user trust.

The third group of questions in the questionnaire consisted of questions about the use of specific types of mobile applications during, and before the coronavirus pandemic. In the first question, the participants had to respond if they were using specific types of mobile applications before the pandemic. In the second question related to the same mobile applications, the participants had to respond if they were using these applications during the pandemic. The mobile applications were divided into the following types: grocery shopping, clothes/footwear/other shopping, gift shopping (clothes/footwear/other) and 
ToSEE - Tourism in Southern and Eastern Europe, Vol. 6, pp. 803-815, 2021.

Z. Zadel, N. Šerić Honović, D. Magaš: THE IMPACT OF THE COVID-19 PANDEMIC ON THE USE ...

delivery to the wanted address, ticket reservation/shopping for cultural events (movies/theatres/museums/other), transport ticket reservation/shopping, parking services and mobile applications for communication. As expected, the results confirmed that the number of users increased for the first three mentioned types of mobile applications as well as for the ones used for communication. The number of users for all the other types of mobile applications decreased which was also not surprising since the public and private transportation were used less during the pandemic, and there were less cultural events, that is, institutions for cultural events were completely shut down for a certain period of time. Even though the participants marked the previous statements related to the frequency of using mobile applications for buying products with points higher than 3, it was clear that the formulated hypothesis could not be accepted because it was not confirmed that the mobile applications (of all types) were used more often during the pandemic. Indeed, the use of mobile applications for buying products increased, but, as it was mentioned, the participants didn't use the other mobile applications to such extent.

In the next question of the third part of the questionnaire, the participants were asked to list the mobile applications they were using during the pandemic. As assumed, they most often used mobile applications for buying clothes, footwear and fashion accessories. These were the following mobile applications: About You, Asos, Zara, Best Secret, Farfetch, Sinsay, H\&M, Froddo, Mango, Zalando, Zapatos, Stradivarius, Bershka, Zaful and eKupi. Also, the participants often used social media applications and mobile applications for communication: Instagram, Facebook, WhatsApp, Viber, Snapchat, Skype, Messenger and Microsoft Teams. The next most often listed applications were the ones for ordering food or other household supplies: Glovo, Wolt, Pauza and Bolt Next, the participants were buying different products using the following sites, i.e. the following mobile applications: eBay, Amazon and Wish. They were also buying, although in a fewer number, cosmetic products through these applications/websites: DM and Notino. Also, the applications/websites for buying groceries were rarely mentioned: Lidl, Konzum and Healthy Food Factory. A few mobile applications for fun and education were also mentioned: YouTube, Netflix, TikTok, Spotify, Pinterest and Campster. Even though there were less travels and cultural events, the participants also used applications for buying tickets for cultural events and transportation: Cinestar, Arriva and Moje karte. Only a few participants listed Google, Google Maps and an online banking application under this type of mobile applications. The previously described data will be presented in the following table for a better comprehension of the results. 
ToSEE - Tourism in Southern and Eastern Europe, Vol. 6, pp. 803-815, 2021.

Z. Zadel, N. Šerić Honović, D. Magaš: THE IMPACT OF THE COVID-19 PANDEMIC ON THE USE ...

Table 2: The types of mobile applications used during the coronavirus pandemic

\begin{tabular}{|c|c|}
\hline The type of mobile application & Mobile application name \\
\hline $\begin{array}{l}\text { Mobile applications for buying clothes, footwear and } \\
\text { fashion accessories }\end{array}$ & $\begin{array}{l}\text { About You } \\
\text { Asos } \\
\text { Zara } \\
\text { Best Secret } \\
\text { Farfetch } \\
\text { Sinsay } \\
\text { H\&M } \\
\text { Froddo } \\
\text { Mango } \\
\text { Zalando } \\
\text { Zapatos } \\
\text { Stradivarius } \\
\text { Bershka } \\
\text { Zaful } \\
\text { eKupi } \\
\end{array}$ \\
\hline Social media applications & $\begin{array}{l}\text { Instagram } \\
\text { Facebook }\end{array}$ \\
\hline Mobile applications for communication & $\begin{array}{l}\text { WhatsApp } \\
\text { Viber } \\
\text { Snapchat } \\
\text { Skype } \\
\text { Messenger } \\
\text { Microsoft Teams }\end{array}$ \\
\hline $\begin{array}{l}\text { Mobile applications for the delivery of prepared } \\
\text { food/household supplies }\end{array}$ & $\begin{array}{l}\text { Glovo } \\
\text { Wolt } \\
\text { Pauza } \\
\text { Bolt }\end{array}$ \\
\hline Mobile applications for buying different products & $\begin{array}{l}\text { eBay } \\
\text { Amazon } \\
\text { Wish } \\
\end{array}$ \\
\hline Mobile applications for buying cosmetic products & $\begin{array}{l}\text { DM } \\
\text { Notino } \\
\end{array}$ \\
\hline Mobile applications for grocery shopping & $\begin{array}{l}\text { Lidl } \\
\text { Konzum } \\
\text { Healthy Food Factory }\end{array}$ \\
\hline Mobile applications for fun and education & $\begin{array}{l}\text { YouTube } \\
\text { Netflix } \\
\text { TikTok } \\
\text { Spotify } \\
\text { Pinterest } \\
\text { Campster } \\
\end{array}$ \\
\hline Mobile applications for buying tickets & $\begin{array}{l}\text { Cinestar } \\
\text { Arriva } \\
\text { Moje karte } \\
\end{array}$ \\
\hline Other mobile applications for everyday use & $\begin{array}{l}\text { Google } \\
\text { Google Maps } \\
\text { Banking applications } \\
\end{array}$ \\
\hline
\end{tabular}

Source: Authors 
ToSEE - Tourism in Southern and Eastern Europe, Vol. 6, pp. 803-815, 2021.

Z. Zadel, N. Šerić Honović, D. Magaš: THE IMPACT OF THE COVID-19 PANDEMIC ON THE USE ...

The review of the used mobile applications once again confirmed the above-mentioned, meaning that the participants mostly used mobile applications for buying clothes, footwear and other fashion accessories. When talking about the differences between men and women in using mobile applications, it was determined that men used mobile applications for buying clothes, footwear and fashion accessories, then for ordering food and other household supplies, for messaging and applications for communication and fun. As for the first mentioned category, the t-test was used to determine if there is a significant difference between men and women in using these applications. The results $(\mathrm{t}=0,083, \mathrm{df}=68, \mathrm{p}>0,05)$ showed there is no significant difference.

\section{CONCLUSION}

The global pandemics are situations happening all around the world which cause various changes in people's lives. Everyone is trying to adapt in a different way so they can be able to fulfil their everyday obligations without difficulties. Most of the people in Croatia worked from home, while the students listened to their school and faculty lessons on the smart devices. Most of the students still haven't returned to face-to-face classes, just as the office is still at home for most of the employees. However, the way of buying groceries, prepared food, clothes, footwear and different services has also changed. A large number of businesses with such offer had mobile applications for attracting potential customers even before the pandemic, and some of them existed even though they were not used as much as during the pandemic.

The purpose of this paper was to determine to what extent has the local population been using different mobile applications during the pandemic as compared to the time before the pandemic. The hypothesis was formulated with the assumption that the results will show the increased use of mobile applications during the pandemic, but the results showed the increase in the number of users who have been using mobile applications for buying clothes, footwear and other fashion accessories, for communication as well as for buying prepared food and household supplies. When talking about the mobile applications for buying and reservation of different tickets as well as travel tickets, the results showed that their use decreased which was expected. Therefore, since the use of one type of mobile applications decreased and the use of the other types increased, it is clear that the hypothesis could not be accepted. The conducted t-test determined there was no significant difference between men and women in using mobile applications. Moreover, when they had to list the applications they have been using the most, there was no significant difference in terms of the connection between the gender of the participants and the applications they listed.

The reason for rejecting the hypothesis, that is, rejecting the obtained results, can be possibly explained by the lack of experience in using mobile applications before the pandemic and/or by inadequate development of mobile applications which are insufficiently accessible to all generations of users. The limit of this research certainly lies in selecting only the participants who use social networks. According to the above, the recommendation for future research would be to conduct a research in order to determine the reasons why the hypothesis of this research could not be accepted. Besides, it is necessary to conduct a research among the visitors of the city of Rijeka to verify if 
ToSEE - Tourism in Southern and Eastern Europe, Vol. 6, pp. 803-815, 2021.

Z. Zadel, N. Šerić Honović, D. Magaš: THE IMPACT OF THE COVID-19 PANDEMIC ON THE USE ...

they use mobile applications regardless of the pandemic and to test if this refers to the mobile applications which the local population listed as being used more often or the ones which were listed as less frequently used. It is recommended to conduct a research among the local population and the visitors when the pandemic is completely over in order to determine if their habits changed or remained the same. Also, it would be interesting to do the same research during and after COVID-19 in other ten smart cities/destinations of Croatia and to compare results with this research. In this way, changes on the supply side would be identified, what is the basis for destination management during pandemic.

\section{ACKNOWLEDGEMENTS}

This paper has been financially supported by the University of Rijeka, for the project ZIP-UNIRI116-1-20.

\section{REFERENCES}

Allen, T., Murray, K.A., Zambrana-Torrelio, C., Morse, S.S., Rondinini, C., Di Marco, M., Breit, N., Olival, K.J. and Daszak, P. (2017), "Global hotspots and correlates of emerging zoonotic diseases", Nature Communications, Vol. 8, No. 1, 1124. https://doi.org/10.1038/s41467-017-00923-8

Beritelli, P., Reinhold, S., Laesser, C. and Bieger, T. (2015), The St. Gallen model for destination management, IMP-HSG, St. Gallen.

Buhalis, D. and Amaranggana, A. (2015), "Smart tourism destinations enhancing tourism experience through personalisation of services", in Tussyadiah, I. and Inversini, A. (Eds), Information and Communication Technologies in Tourism 2015, Springer, Cham, pp. 377-390. https://doi.org/10.1007/978-3-319$14343-928$

Burkle, F.M. Jr, (2006), "Globalization and disasters: Issues of public health, state capacity and political action”, Journal of International Affairs, Vol. 59, No. 2, pp. 231-265.

Boes, K., Buhalis, D. and Inversini, A. (2015), "Conceptualising smart tourism destination dimensions", in Tussyadiah, I. and Inversini, A. (Eds), Information and Communication Technologies in Tourism 2015., Springer, Cham, pp. 391-403. https://doi.org/10.1007/978-3-319-14343-9_29

Bressler, H. (2010), "The future of mobile and destination marketing", available at: www.slideshare.net/hillarybressler/future-of-mobile-for-destination-marketing-and-travel

Caragliu, A., Del Bo, C. and Nijkamp, P. (2011), "Smart cities in Europe", Journal of Urban Technology, Vol. 18, No. 2, pp. 65-82.

Dredge, D. (1999), "Destination place planning and design", Annals of Tourism Research, Vol. 26, No. 4, pp. 772-791. https://doi.org/10.1016/S0160-7383(99)00007-9

Gössling, S., Scott, D. and Hall, C.M. (2020), "Pandemics, tourism and global change: a rapid assessment of COVID-19", Journal of Sustainable Tourism, Vol. 29, No. 1, pp. 1-20 https://doi.org/10.1080/09669582.2020.1758708

Gössling, S., Scott, D. and Hall, C.M. (2020), "Pandemics, transformations and tourism: be careful what you wish for", Tourism Geographies, Vol. 22, No. 3, 577-598. https://doi.org/10.1080/14616688.2020.1759131

Gretzel, U., Sigala, M., Xiang, Z. and Koo, C. (2015), "Smart tourism: Foundations and developments", Electronic Markets, Vol. 25, No. 3, pp. 179-188. https://doi.org/10.1007/s12525-015-0196-8

Guo, Y., Liu, H. and Chai, Y. (2014), "The embedding convergence of smart cities and tourism internet of things in China: An advance perspective", Advances in Hospitality and Tourism Research, Vol. 2, No. 1, str. 54-69.

Hall, C.M. (2020), "Biological invasion, biosecurity, tourism, and globalization", in Timothy, D. (Ed.), Handbook of globalisation and tourism, Edward Elgar, pp.114-125.

Institut za Turizam, Stavovi i potrošnja turista u Hrvatskoj, Tomas Hrvatska 2019, viewed 19 April 2021, http://www.iztzg.hr/files/file/RADOVI/KNJIGE/TOMAS-Hrvatska-2019.pdf 
ToSEE - Tourism in Southern and Eastern Europe, Vol. 6, pp. 803-815, 2021.

Z. Zadel, N. Šerić Honović, D. Magaš: THE IMPACT OF THE COVID-19 PANDEMIC ON THE USE ...

Ivars Baidal, J.A., Solsona Monzonís, F.J. and Giner Sánchez, D. (2016), “Gestión turística y tecnologías de la información y la comunicación (TIC): El nuevo enfoque de los destinos inteligentes", Documents d'Anàlisi Geogràfica, Vol. 62, No. 2, pp. 327-346. http://dx.doi.org/10.5565/rev/dag.285

Lamsfus, C., De Canto, D.M., and Alzua-Sorzabal, A. (2015), "Smart Tourism Destinations: An Extended Conception of Smart Cities Focusing on Human Mobility", Information and Communication Technologies in Tourism 2015: Proceedings of the International Conference in Lugano, Switzerland, pp. 363-375. https://doi.org/10.1007/978-3-319-14343-9_27

Leiper, N. (1990), "Tourist attraction systems", Annals of Tourism Research, Vol. 17, No. 3, pp. 367-384 https://doi.org/10.1016/0160-7383(90)90004-B

Liberato, P., Alen, E., Liberato, D, (2018), "Smart tourism destination triggers consumer experience: the case of Porto", European Journal of Management and Business Economics, Vol. 27, No. 1, pp. 6-25. https://doi.org/10.1108/EJMBE-11-2017-0051

Lii Inn, T. (2020), "Smart City Technologies Take on Covid-19”, Penang Institute.

Narodne novine, Law of tourist boards and the promotion of croatian tourism, viewed 19 April 2021, https://narodne-novine.nn.hr/clanci/sluzbeni/2019 05 52 990.html

Neuhofer, B., Buhalis, D. and Ladkin, A. (2012), "Conceptualising technology enhanced destination experiences”, Journal of Destination Marketing Management, Vol. 1 No. 1, pp. 36-46.

Paulino, I., Lozano, S and Prats, L. (2021), "Identifying tourism destinations from tourists' travel patterns", Journal of Destination Marketing \& Management, Vol. 19, 100508 https://doi.org/10.1016/j.jdmm.2020.100508

Presenza, A., Micera, R., Splendiani, S., and Del Chiappa, G. (2014), "Stakeholder e-involvement and participatory tourism planning: analysis of an Italian case study", International Journal of Knowledge Based Development, Vol. 5, No. 3, pp. 311-328.

Ritchie, J.R. and Crouch, G.I. (2005), "A model of destination competitiveness", in Competitive destination: A sustainable tourism perspective, Cabi, Wallingford, pp. 60-78.

Santos-Júnior, A., Mendes-Filho, L., Almeida García, F. and Simões, J. (2017), Smart Tourism Destinations: a study based on the view of the stakeholders, Revista Turismo em Análise, Vol. 28, pp. 358-379.

Sigalat-Signes, E., Calvo-Palomares, R., Roig-Merino, B. and Garcia-Adan, I. (2019), "Transition towards a tourist innovation model: The smart tourism destination Reality or territorial marketing?", Journal of Innovation \& Knowledge, Vol. 5, No. 2., pp. 2444-2569. https://doi.org/10.1016/j.jik.2019.06.002

Wang, D., Park, S. and Fesenmaier, D. (2012), "The role of smartphones in mediating the tourism experience", Journal of Travel Research, Vol. 51, No. 4, pp. 371-387. https://doi.org/10.1177/0047287511426341

World Tourism organization UNWTO, n.d., Global Guidelines to Restart Tourism, viewed 19 April 2021 https://webunwto.s3.eu-west-1.amazonaws.com/s3fs-public/2020-05/UNWTO-GlobalGuidelines-to-Restart-Tourism.pdf

Xiang, Z., Magnini, V.P. and Fesenmaier, D.R. (2015), "Information technology and consumer behavior in travel and tourism: Insights from travel planning using the internet", Journal of Retailing and Consumer Services, Vol. 22, pp. 244-249. https://doi.org/10.1016/j.jretconser.2014.08.005

Zhu, W., Zhang, L. and Li, N. (2014), "Challenges, Function Changing of Government and Enterprises in Chinese Smart Tourism", Information and communication technologies in tourism, Vol. 10, pp $553-564$. 
ToSEE - Tourism in Southern and Eastern Europe, Vol. 6, pp. 803-815, 2021.

Z. Zadel, N. Šerić Honović, D. Magaš: THE IMPACT OF THE COVID-19 PANDEMIC ON THE USE ...

Zrinka Zadel, Ph.D., Associate Professor

University of Rijeka, Faculty of Tourism and Hospitality Management, Opatija Tourism Department

Ika, Primorska 46, p.p. 97, 51410 Opatija, Croatia

+385-51-294 183

zrinkas@fthm.hr

Nikolina Šerić Honović, MA, PhD Student

University of Rijeka, Faculty of Tourism and Hospitality Management, Opatija Tourism Department

Ika, Primorska 46, p.p. 97, 51410 Opatija, Croatia

$+385-51-294183$

nseric@fthm.hr

Damir Magaš, MA, PhD Student

University or Rijeka, Faculty of Tourism and Hospitality Management

Primorska 46, p.p. 97, 51410 Opatija, Croatia

$+385-98-566740$

damir.magas@fthm.hr 